Szegedi Tudományegyetem, Általános Orvostudományi Kar, Arc-, Állcsont- és Szájsebészeti Klinika*

Dr. Kocsis András Fogszabályzó Centrum, Szeged ${ }^{\star \star}$ dicomLAB Kft., Szeged ${ }^{\star \star \star}$

Szegedi Tudományegyetem, Általános Orvostudományi Kar, Traumatológiai Klinika****

\title{
Virtuális modell-mútét és az okklúziós lemez háromdimenziós nyomtatása súlyos mandibula aszimmetria esetében
}

\author{
DR. SERES LÁSZLÓ*, DR. KOCSIS ANDRÁS**, DR. IFJ. VARGA ENDRE ${ }^{* * *}$, DR. RASKÓ ZOLTÁN*, \\ DR. VARGA VIRÁG**, BAGÓ BALÁZS***, DR. VARGA ENDRE**** DR. PIFFKÓ JÓZSEF*
}

\begin{abstract}
A hagyományos, kétdimenziós kefalometriai elemzések kevés segítséget nyújtanak az aszimmetrikus fejlődési rendellenességek kezelésének tervezéséhez. A modell-mútét sokszor időigényes, bonyolult és tévedésekhez is vezethet. Tanulmányunk célja egy olyan, súlyos arc-aszimmetriával járó eset bemutatása, ahol a mútétet és az okklúziós lemezt virtuálisan terveztük. Egy 26 éves férfit jobboldali hemimandibularis elongációval és a maxilla okklúziós síkjának kompenzatórikus dőlésével diagnosztizáltunk. A fogszabályozó előkészítést követően nagy felbontású komputertomográf felvételeket készítettünk. A háromdimenziós struktúrák rekonstrukcióját és a virtuális mútétet saját fejlesztésū tervezőprogrammal végeztük. A mútéti sínt virtuálisan terveztük, majd háromdimenziós nyomtatóval készítettük el. A valós mútét a számítógépes tervezés alapján történt. Az okklúziós sín a mútét közben tökéletesen illeszkedett. Az arc szimmetriája a mútétet követően nagymértékben javult. Esetünk azt mutatja, hogy a háromdimenziós tervezőprogramok komoly segítséget adhatnak az állcsontkorrekciós mútétek tervezéséhez és elvégzéséhez. Feleslegessé tehetik a fogtechnikai hátteret, a bonyolult modell-mütét elvégzését.
\end{abstract}

Kulcsszavak: virtuális modell-mútét, arc-aszimmetria, komputervezérelt sebészet, virtuális mútéti sín, háromdimenziós nyomtatás

\section{Bevezetés}

A fogazat, az arc csontjai és a körülöttük lévő lágyrészek összetett geometriai tulajdonságai miatt az arcaszimmetria kezelése komoly kihívás elé álítja az ellátó orvosokat. A mandibula aszimmetriája általában együtt jár a maxilla kompenzatórikus dőlésével és ferde okklúziós síkkal, ezért a legtöbb esetben bimaxilláris oszteotómiára van szükség [1].

A hagyományos kefalometriai analízisek az aszimmetria okát korlátozott mértékben magyarázzák, mivel komplex háromdimenziós struktúrákat vetítenek le kétdimenziós felületekre. Egy aszimmetrikus eset kezelési terve háromdimenziós szemléletet igényel szagittális, vertikális és horizontális síkban egyaránt. A sok és időigényes laboratóriumi lépést igénylő modell-mútét nélkülözhetetlen része a preoperatív előkészítésnek. Bimaxilláris mútét esetén az arcíves regisztrációt követően az egyéni értékű artikulátorban levő gipszmodellen végezzük el a maxilla megfelelő pozícióba történő áthelyezését, majd egy mútéti sínt készítünk, amely a valós mútét alatt az intakt mandibulához állítja be a maxilla új helyzetét. A második, vagy végleges lemez a mobilizált mandibula végleges helyzetét rögzíti a már fixált maxillához [2].
A modell-mútét során kiemelkedően fontos, hogy azt a mütéti tervnek megfelelően a lehető legpontosabban végezzük. Bármilyen eltérés a terv és a modell-mútét között az okklúziós lemez pontatlanságához vezet, aminek a végeredmény szempontjából súlyos következményei lehetnek. Komplex bimaxilláris mútét esetén a modell-mútét bonyolult lehet, és esetleges hibákat hordozhat magában [3].

A nagyfelbontású $C T$ vizsgálat és a számítógépvezérelt sebészet új utat nyitott a maxillofaciális deformitások korrekciós kezelésében. A háromdimenziós nyomtatás egy figyelemreméltó, gyorsan fejlődő technológia, amely sok területen forradalmasította a különböző, ezelőtt hagyományos módszerekkel készített anyagok előállítását. Az állcsontkorrekciós sebészetben az ezzel a technológiával készített sínek a mobilizált állcsontok pontosabb beállítását segíthetik $[4,5]$.

Tanulmányunkban azt vizsgáltuk, hogy egyrészt a virtuális háromdimenziós modell-mútét alkalmas lehet-e bonyolult bimaxilláris beavatkozások tervezésére, másrészt pedig, hogy az így megtervezett és háromdimenziós nyomtatóval előállított okklúziós lemezek kiválthatják-e a fogtechnikai laboratóriumban hagyományos technológiával készülő síneket. 

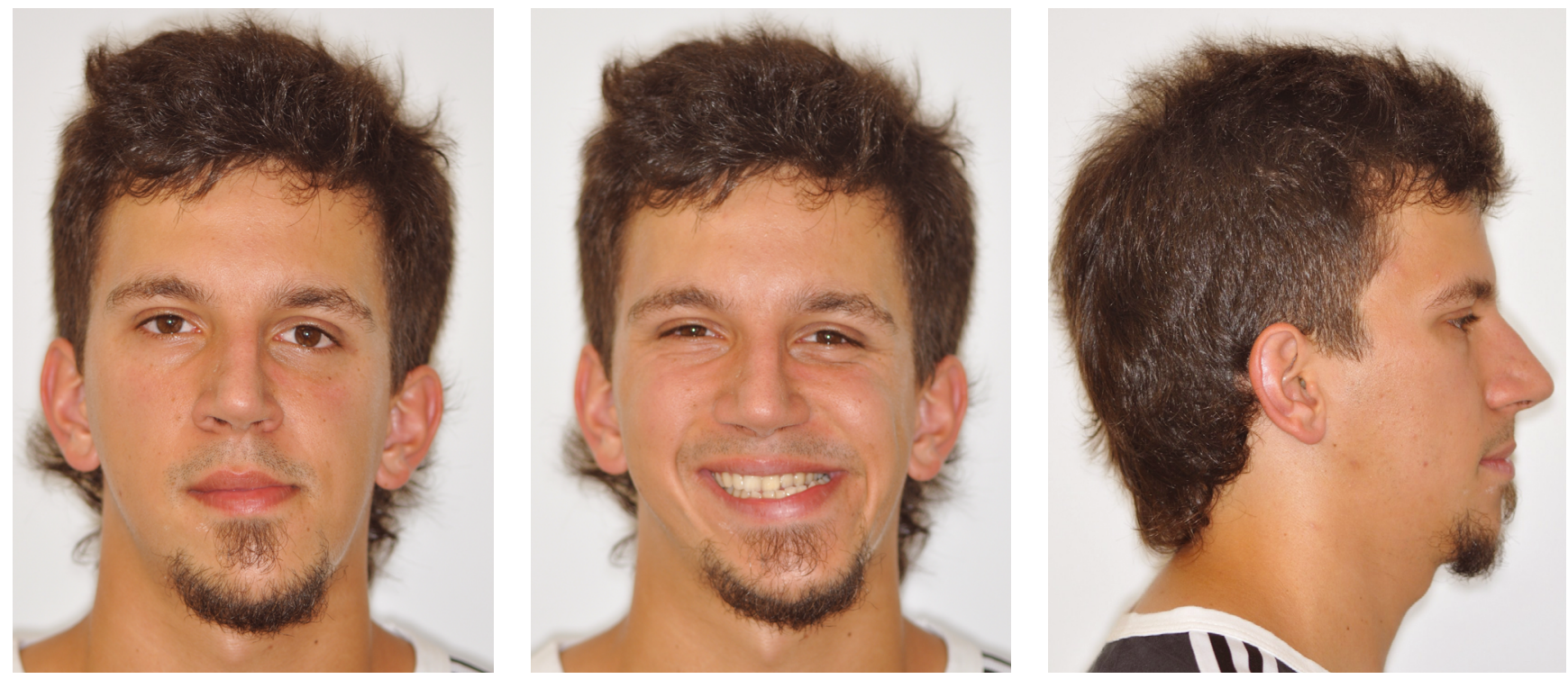

1a., b., c. ábra: Kezelés előtti arcfotók
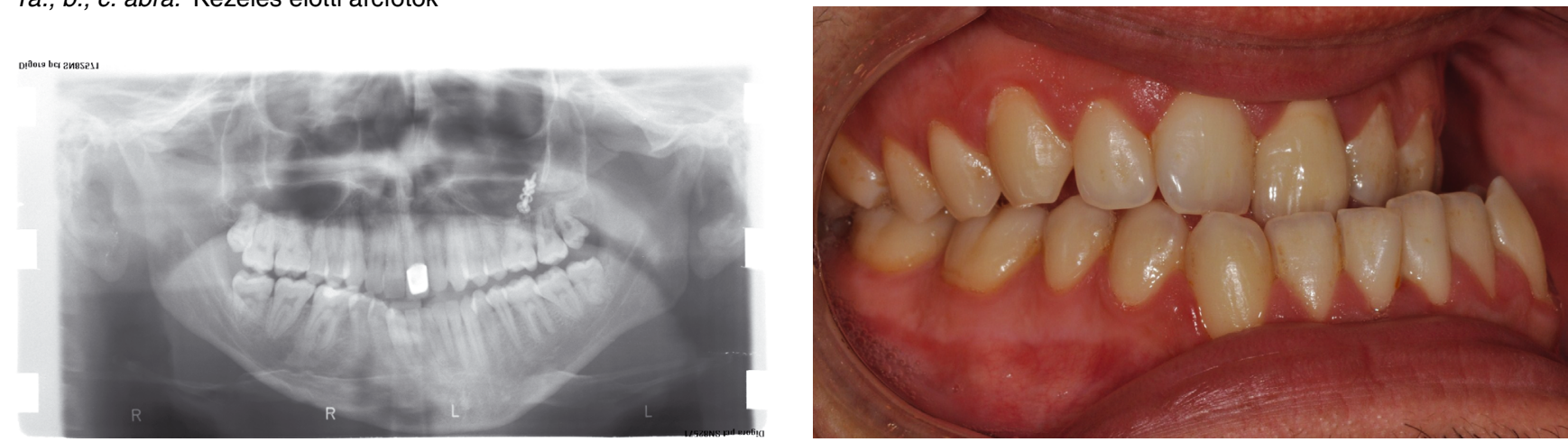

2. ábra: Kezelés előtti panorámaröntgen

Egy súlyos arc-aszimmetriával járó esetet mutatunk be, ahol a mútétet és a mútéti sínt virtuálisan terveztük, majd az utóbbit háromdimenziós nyomtatóval készítettük el.

\section{Beteg és módszer}

26 éves férfibeteg jelentkezett klinikánkon súlyos arcaszimmetriával (1a., b., c. ábra) és rágási nehézséggel. A klinikai és radiológiai vizsgálatok súlyos jobb oldali hemimandibuláris elongációt és az okklúziós sík mérsékelt fokú kompenzatórikus ferdeségét mutatták. A szagittális síkban a jobb oldalon Class III, míg a bal oldalon Class I okklúziós viszonyokat észleltünk a molárisok és a szemfogak területén. Az alsó frontfogak, a bal oldali alsó premolárisok és molárisok linguál felé dőltek. A bal oldalon keresztharapás volt látható. A felső metszők középvonala az arc középvonalával egybeesett. A mandibula dentális középvonala $11,8 \mathrm{~mm}$ rel, a mentum $15 \mathrm{~mm}$-rel deviált balra (2., 3., 4a. ábra). Mindkét fogíven mérsékelt torlódás volt észlelhető. A technécium izotóp vizsgálat nem mutatott fokozott aktivitást a kondiláris régióban.
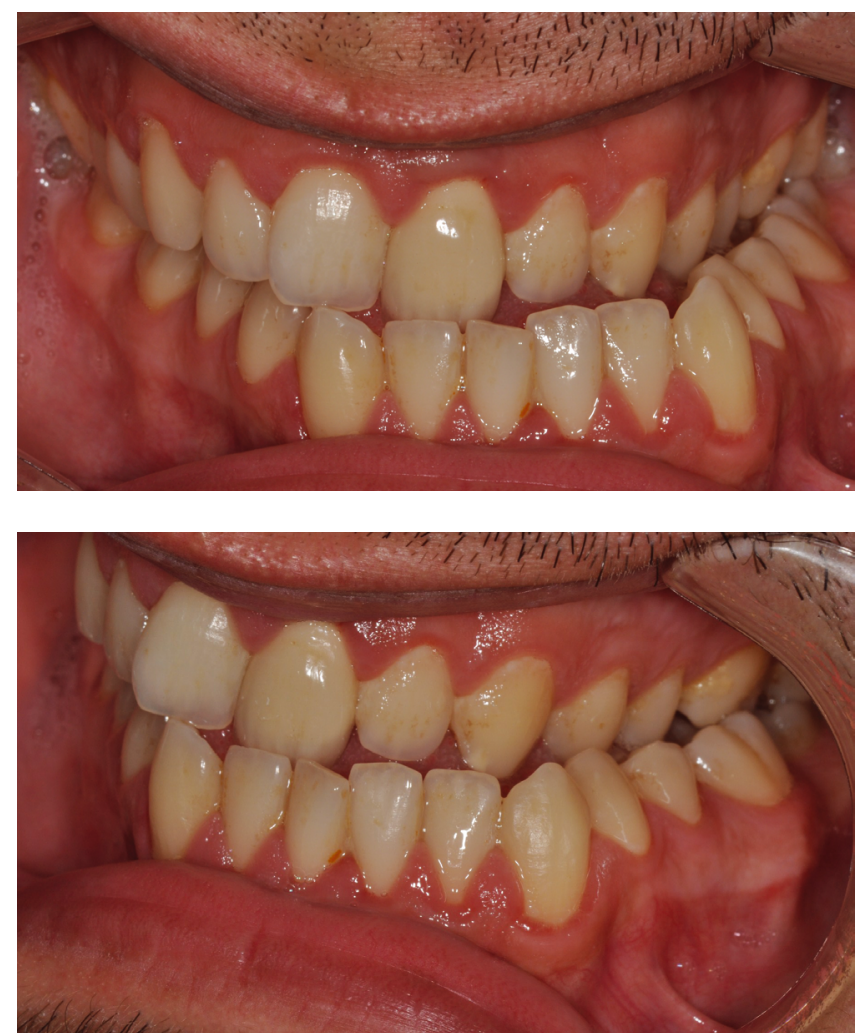

3a., b., c. ábra: Kezelés előtti intraorális felvételek 


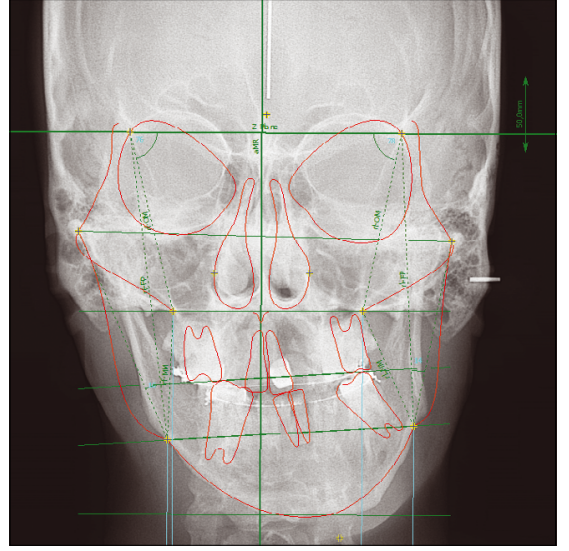

4a. ábra: Kezelés előtti

PA teleröntgen mutatja a maxilla kompenzatórikus dőlését
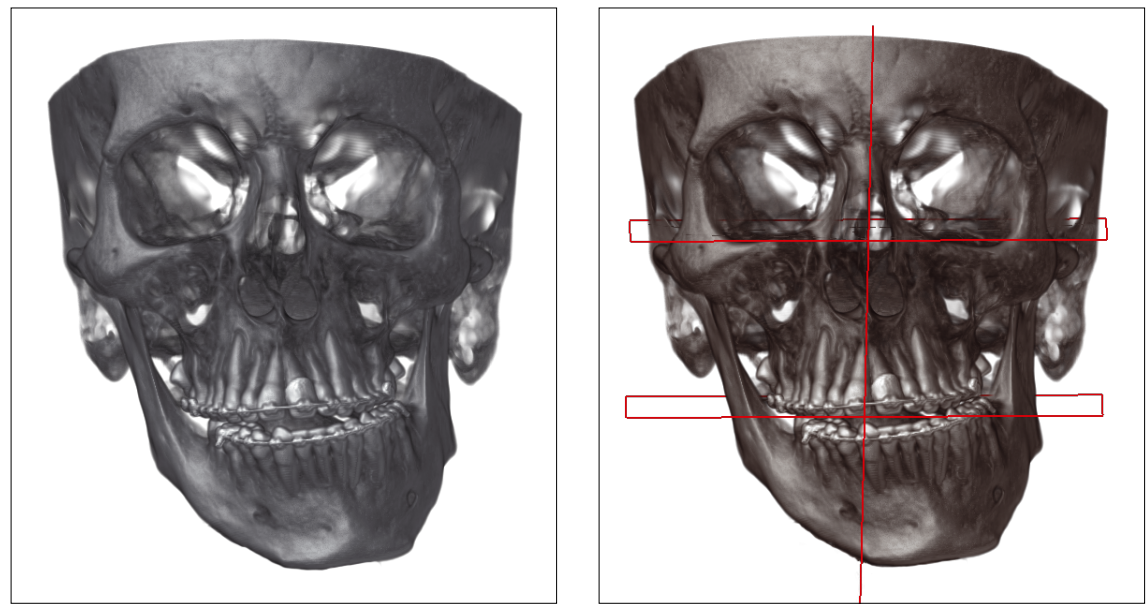

5a., b. ábra: Preoperatív CT rekonstrukció; referencia-síkokkal
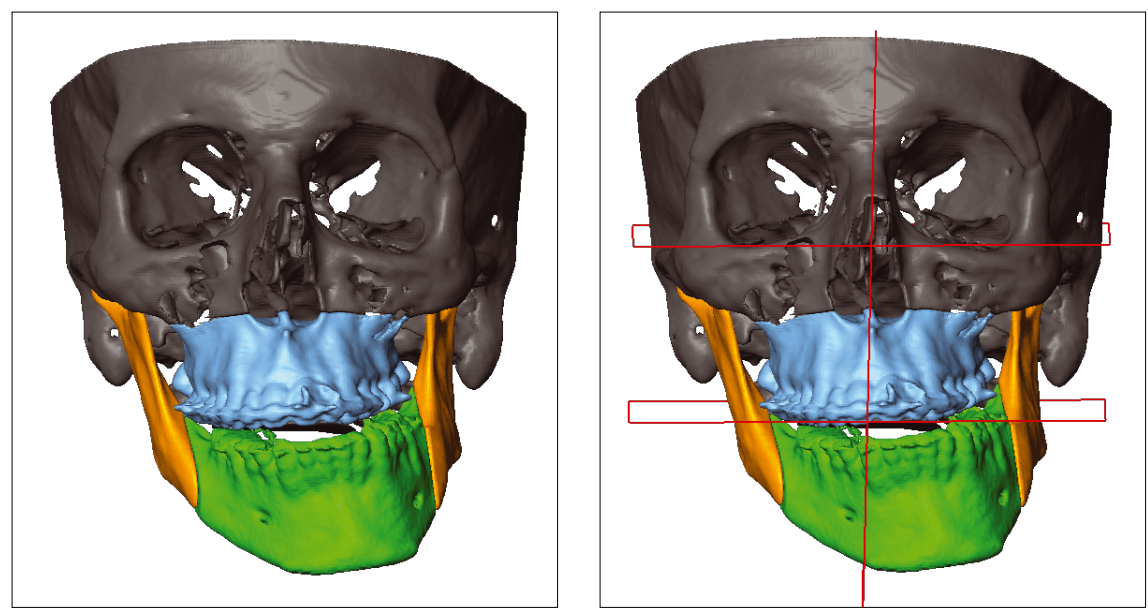

6a., b. ábra: A csontos struktúrák kiválasztása; referencia-síkokkal

mert volt, de az ortodonciai-sebészi kezelést ezt megelőzően nem vállalta, a járomcsont-mútétet követően azonban beleegyezett a kezelésbe.

A preoperatív ortodonciai kezelés 18 hónapig tartott, a transzverzális és szagittális dentális kompenzáció megszüntetéséből, szabályos fogívek kialakításából és a fogívek harmonizációjából állt. Ebben a szakaszban nem törekedtünk a vertikális diszkrepancia megoldására.

Az oldalirányú kefalometriai elemzéseket Hasund szerint végeztük OnyxCeph (Image Instruments $\mathrm{GmbH}$, Chemnitz, Németország) program segítségével (4b. ábra). Ezt követően nagy felbontású, 0,3 mm-es szeletvastagsággal készült $C T$ vizsgálatot végeztünk standard paraméterekkel (60kVp / 40keV / $900 \mu \mathrm{A})$. A beteget hanyatt fekvő helyzetben vizsgáltuk meg, a vizsgálóasztal teljesen vízszintes helyzete mellett. A DICOM formátumú adatokat személyi számítógépre vittük fel és saját fejlesztésű háromdimenziós tervezőszoftvert (JMed szoftver, dicomLAB Kft., Szegedi Tudományegyetem) használtunk a háromdimenziós struktúrák rekonstrukciójához, valamint a preoperatív mútéti tervezéshez. A felszíni modellek rekonstrukcióját a JMed program „Get Surface” parancsa alapján végeztük el [6] (5a., b. ábra).

A csontos struktúrák kiválasztása félautomata szegmentációs algoritmus alkalmazásával a szoftver szegmentációs eszközkészletével történt [7] (6a., b. ábra). Háromdimenziós kefalometriai elemzést követően a modellen virtuális Le Fort I oszteotómiát végeztünk. A mobilizált szegmentumot úgy rotáltuk, hogy a maxilla szimmetrikus helyzetbe kerüljön (7a., b. ábra). Ezt követően virtuális sebészi okklúziós lemezt terveztünk: a felső és alsó állcsont között a Le Fort I oszteotómiát követően megváltozott viszonyokat mentettük el, majd Amira $^{\circledR}$ rendszerbe vittük át, ami egy kereskedelmi forgalomban el-

Kórtörténetéből kiemelendő, hogy 25 éves korában bal oldali járomcsonttörést szenvedett, melyet klinikánkon láttunk el. Arc-aszimmetriája ekkor már több éve is- érhető, kép megjelenítésére és adat analizálására alkalmas programcsomag (Visage Imaging $\mathrm{GmbH}$, Berlin, Németország). 

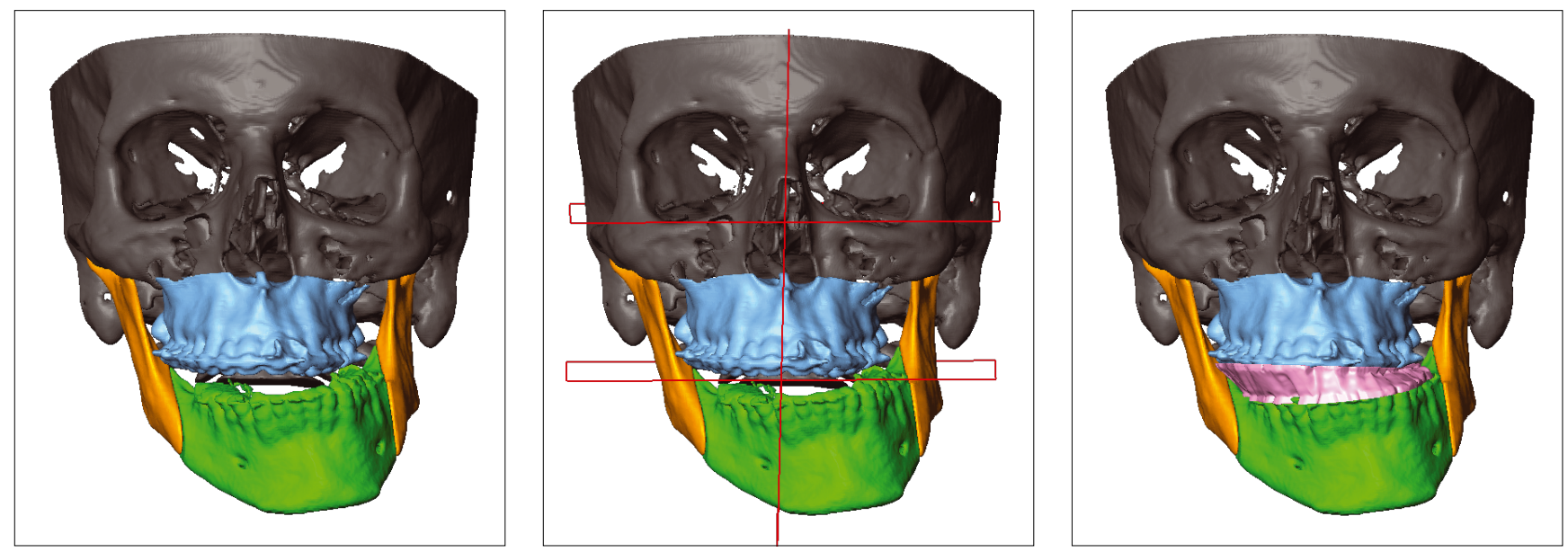

7a., b., c. ábra: A maxilla új helyzetében; referencia-síkokkal; a virtuális okklúziós lemez a Le Fort I oszteotómia után
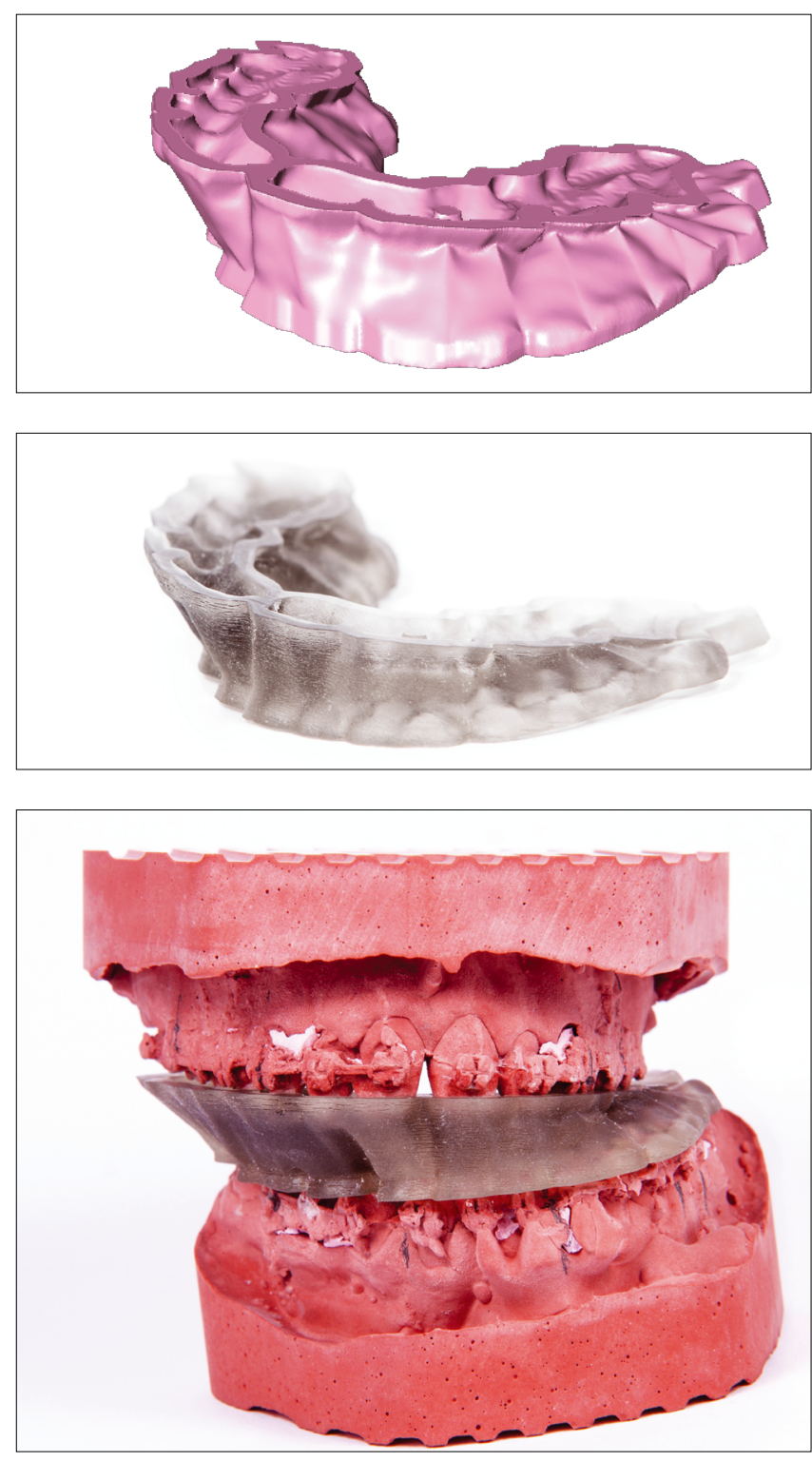

8a., b., c. ábra: A virtuális okklúziós lemez; a valódi okklúziós lemez; a valódi okklúziós lemez a gipszmintában
A fogak okklúziós felszíneit kijelöltük, majd további képfeldolgozási lépéseket végeztünk. A mútéti sín végső felületi modellje a szoftver „Boolean operation” funkciójának használatával készült és *.stl file-ként lett elmentve (7c. ábra).

$A z$ *.stl file-t háromdimenziós nyomtatóra (Objet Polyjet technology, Objet Geometry Ltd., Tel Aviv, Izrael) küldtük át, ami egy biokompatibilis anyagból (Objet MED610) - ami alkalmas rövid távú nyálkahártya kontaktusra - elkészítette a valódi okklúziós lemezt. A nyomtatási pontosságot a legmagasabb értékre állítottuk, ami a Z-tengelyen 16 mikron nagyságrendú (8a., b., c. ábra).

$A$ virtuális mútét következő részeként a mandibula bilaterális szagittális oszteotómiáját és megfelelő helyzetbe történő rotációját végeztük azzal a céllal, hogy az oszteotomizált szegmentumok mozgatását vizualizáljuk (9a., b. ábra).

A sebészi fázisban a Le Fort I oszteotómiát követően a mobilizált maxillát a tervnek megfelelően rotáltuk, majd a virtuálisan megtervezett okklúziós lemez és mandibulo-maxilláris fixáció segítségével reponáltuk. $A z$ oszteoszintézist minilemezek segítségével végeztük el. Ezután a mandibulo-maxilláris fixációt oldottuk, és kétoldali szagittális oszteotómiát végeztünk a mandibulán. A mandibula testét jobbra forgattuk és a kívánt okklúziós helyzetbe hoztuk. Végső okklúziós lemezt nem használtunk, mivel a fogak jó, egyértelmú, stabil okklúziós helyzetben illeszkedtek. Titán minilemezekkel és csavarokkal oszteoszintézist végeztünk. A posztoperatív intermaxilláris rögzítést két hétig tartottuk fenn. További tíz hétig rugalmas gumihúzást végeztünk a mandibula kezdetben minimális, majd egyre növekvő mozgathatóságával.

A mútét után az ortodonciai kezelés folytatódott. A fogívek végleges harmonizációja és az okklúzió pontos beállítása 6 hónapig tartott. Egy évvel az első beavatkozás után állcsúcsplasztikát és orrsövénymútétet végeztünk a behelyezett rögzítő fémanyagok eltávolításával egy időben. Sablont nem használtunk, standard 

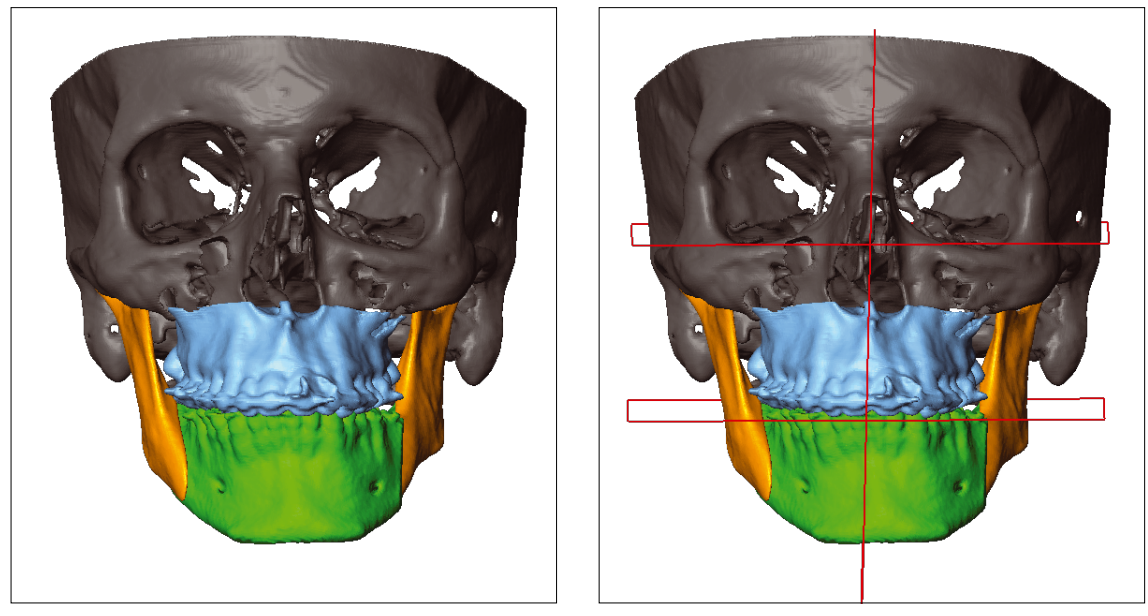

9a., b. ábra: A mandibula új helyzetében; referencia-síkokkal ból, hogy össze tudjuk hasonlítani a virtuális és a valós mútét eredményét. $A$ két rekonstrukció szuperimpozícióját végeztük, a terv és a valós eredmény közötti eltéréseket színtérképen ábrázoltuk.

\section{Eredmények}

A bimaxilláris mútét a virtuális mütéti tervnek megfelelően zajlott le. A sín a mútét alatt tökéletesen illeszkedett (10. ábra). Az arc szimmetriája jelentősen javult a mútét után. Az okklúzió kiegyensúlyozott,
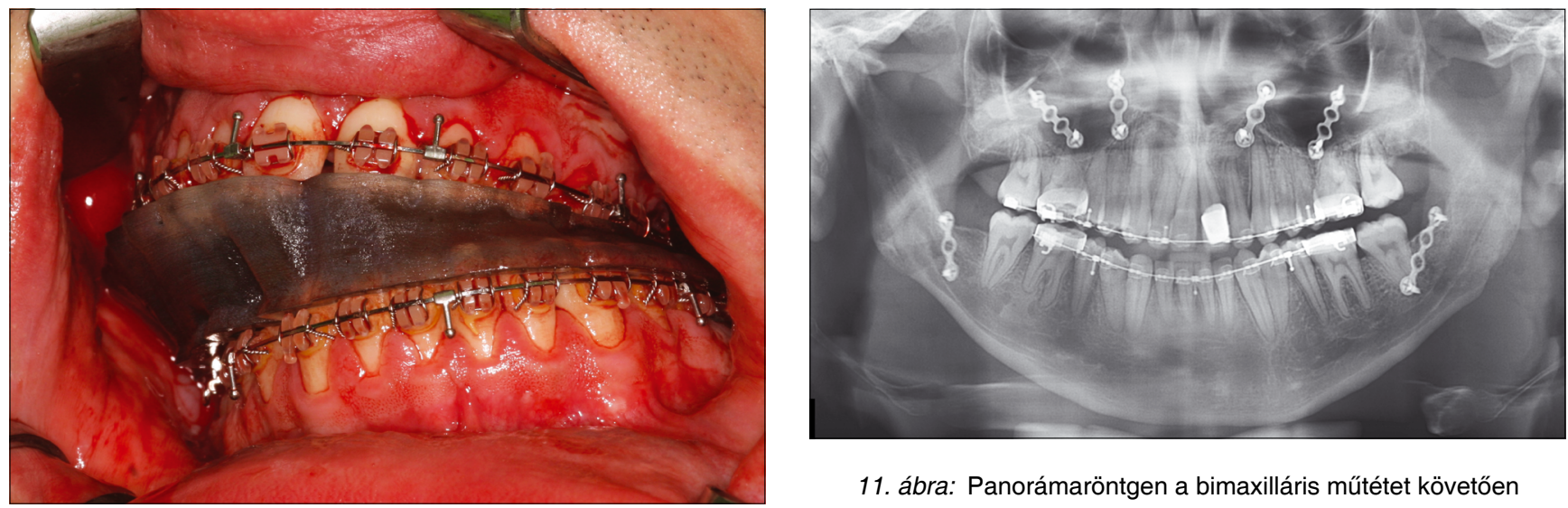

11. ábra: Panorámaröntgen a bimaxilláris mútétet követően

10. ábra: Mútét közben az okklúziós lemez tökéletesen illeszkedett az alsó és a felső fogsorra

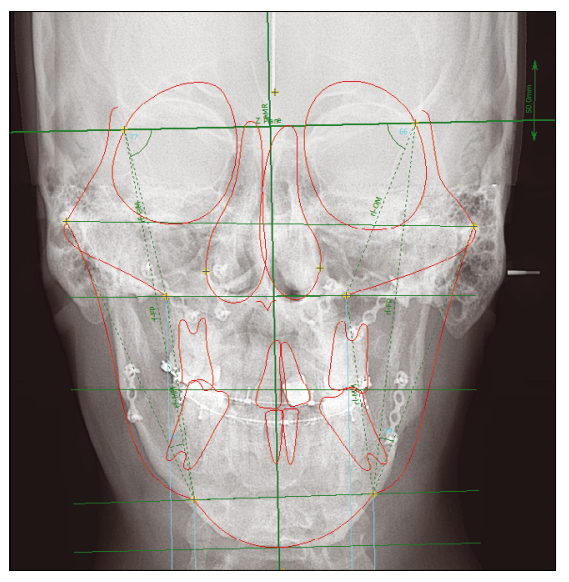

12a. ábra: A mútétet követően készült PA teleröntgen az arc aszimmetriájának lényeges javulását mutatja

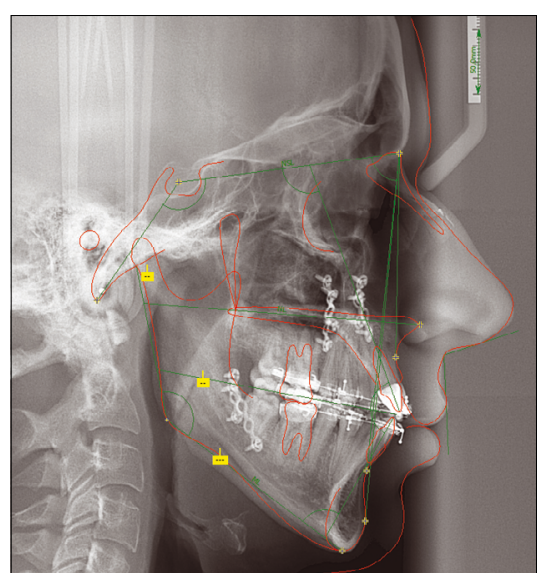

12b. ábra: A mútétet követő oldalirányú kefalometriai elemzés

stabil, a dentális középvonal egybeesik. A beteg elégedett arcának megjelenésével. Relapszusra utaló klinikai jel 18 hónappal az első mútéti beavatkozás után nem észlelhető (11., 12., 13., 14., 15. ábra). A CT-felvételek szuperimpozíciója a terv és a valós eredmény közötti minimális eltérést ábrázolt (16a., b. ábra).

\section{Megbeszélés}

A kraniomaxillofaciális deformitások korrekciója a helyes diagnózis és kezelési terv felállításán múlik. Ha egy szimmetrikus vagy mérsékelten aszimmetrikus arc mútétjéről van szó, amikor

preoperatív mérések alapján az állcsúcsot $4 \mathrm{~mm}$-rel jobbra forgattuk.

Posztoperatív CT vizsgálatot végeztünk abból a cél- az állcsontokat föleg anteroposzterior és vertikális irányban mozgatjuk, a kétdimenziós analízis és tervezés általában elegendő. Azonban még ezekben az esetekben is össze- 

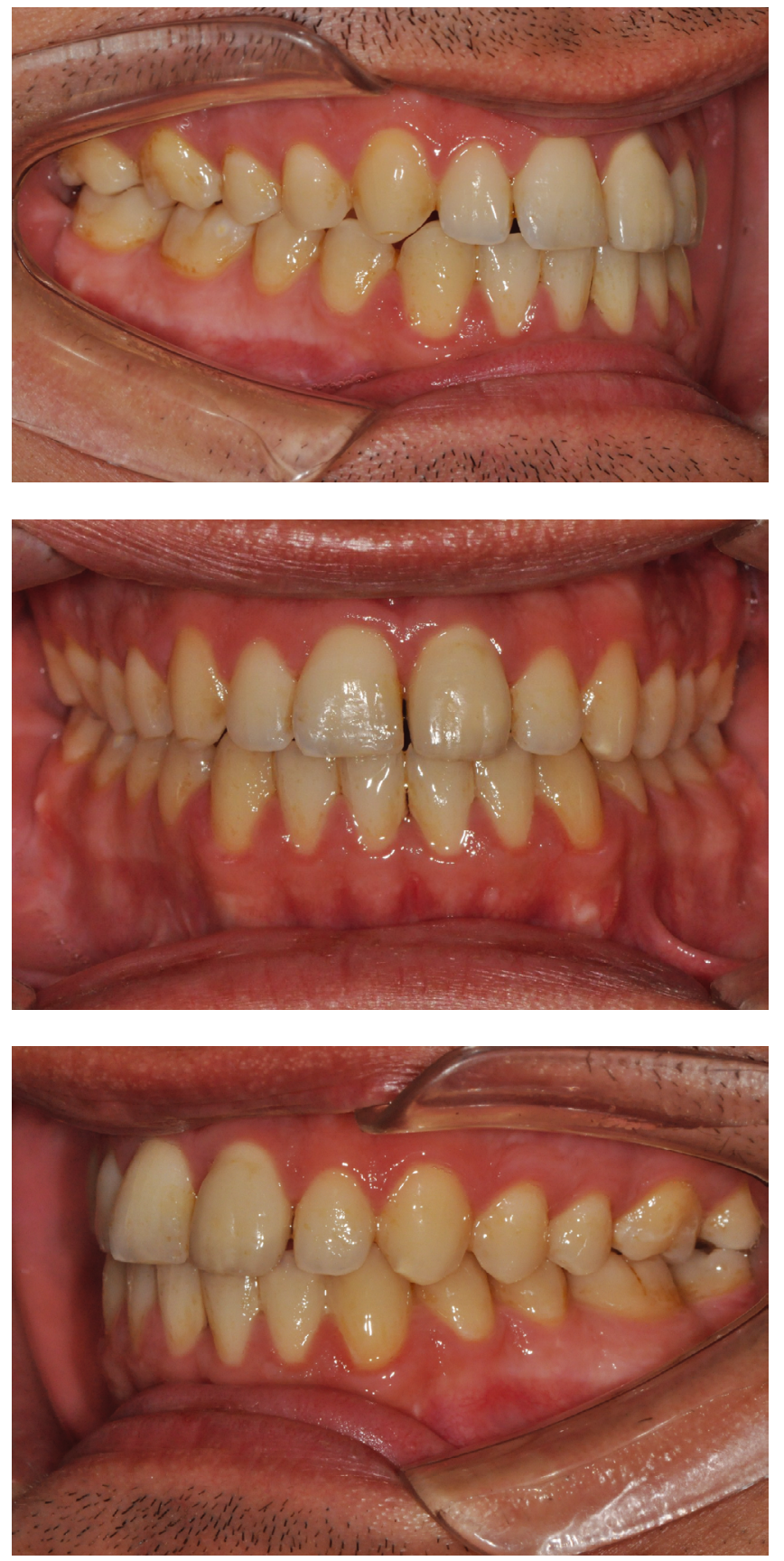

13a., b., c. ábra: Okklúzió a kezelés után

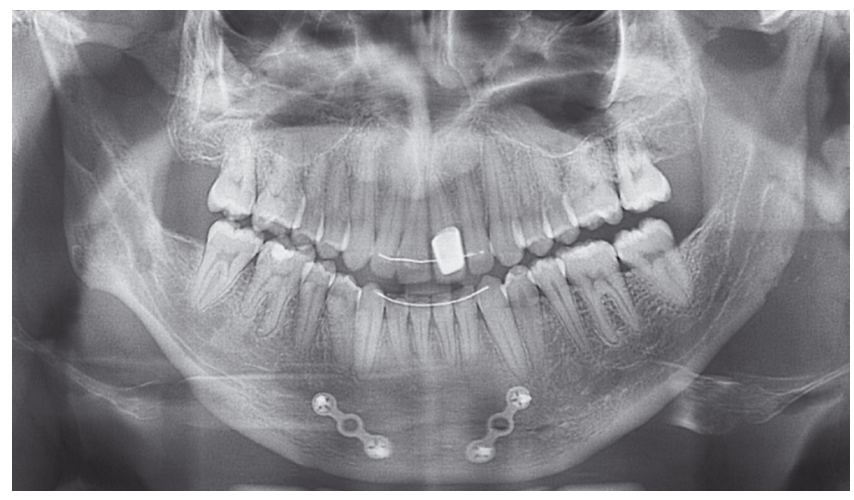

14. ábra: Panorámaröntgen a kezelés után adódhatnak a modell-mútét egyes lépéseinél fellépő apró hibák, és pontatlan eredményhez vezethetnek [7, 8].

Súlyosabb aszimmetria, amely mind az alsó, mind a felső állcsontot érinti, gyakran komplikált, esetleg több lépésből álló bimaxilláris mútétet tesz szükségessé. Ilyen esetben a háromdimenziós tervezés alapvető követelmény. A probléma kettős: egyrészt, hogyan érhető el a legpontosabb tervezés; másrészt, hogyan lehet a mútéti tervet a sebészi beavatkozás során minél tökéletesebben megvalósítani. Kétdimenziós röntgenfelvételek alapján pontos analízis és tervezés aligha lehetséges [10, 11, 12].

A képalkotó eljárások és a tervező szoftverek fejlődése a háromdimenziós számítógépes modellezést a kutatás és fejlesztés szintjéről a rutin klinikai alkalmazás szintjére emelték $[13,14,15]$. A háromdimenziós rekonstrukciós képek minden irányba forgathatók, minden szögből elemezhetők. Pontos mérések végezhetők, így nemcsak a faciális aszimmetria etiológiáját segítenek megérteni, hanem az oszteotómiák megtervezését és a szegmentumok mozgatását is.

Aszimmetrikus arc bimaxilláris mútétjének tervezésekor a felső állcsont térbeli mozgatása sokkal bonyolultabb, mint az alsó állcsonté. A maxilla helyzetét meghatározó mútéti sínek használata sokkal gyakoribb, mint a mandibula helyzetét pozicionáló végleges lemezeké [16].

Esetünkben is a maxilla pontos repozíciója volt a folyamat kulcspontja. A Le Fort I oszteotómia segítségével mobilizált szegmentum elfogadható belső szimmetriát mutatott, ezért további maxilláris oszteotómiákra nem volt szükség. Az okklúziós sík kompenzatórikus dőlésének korrigálására a mobilizált maxillát a transzverzális síkban az óramutató járásának megfelelően addig forgattuk, míg a maxilláris okklúziós sík az orbitális síkkal párhuzamos lett. Ezzel egy időben további rotációt végeztünk a horizontális síkban azért, hogy a maxillát szimmetrikus helyzetbe hozzuk. Többek között az ilyen komplex rotációs mozgás lehet a manuális modell-mútét pontatlanságainak forrása. Amíg a hagyományos módszer esetén a kezelési terv felállítása és a modell-műtét elvégzése két különálló lépés, a virtuális mútéti technikánál ez a két folyamat egy időben történhet, nincs információvesztés a két lépés között. A legbonyolultabb mozgatási múveletek is precízen elvégezhetők, és a legpontosabb mérések is kivitelezhetők ezzel egy időben. A virtuális modell-mútét végső terméke, az okklúziós lemez létrehozható háromdimenziós nyomtató segítségével. A technika sikerességének alapja a virtuális modell és az okklúziós lemez kivitelezésének pontossága [16]. Esetünkben a nyomtatási pontosságot a legmagasabb értékre állítottuk; az így létrehozott mútéti sín minden szempontból alkalmasnak bizonyult a virtuális tervnek a valós mútétre való átvitelére.

A mandibula új pozícióját a már új helyére került maxilla határozta meg. A virtuális sebészeti tervnek megfelelően a mandibula testét a bal oldalon 8,6 mmrel mozdítottuk előbbre. 

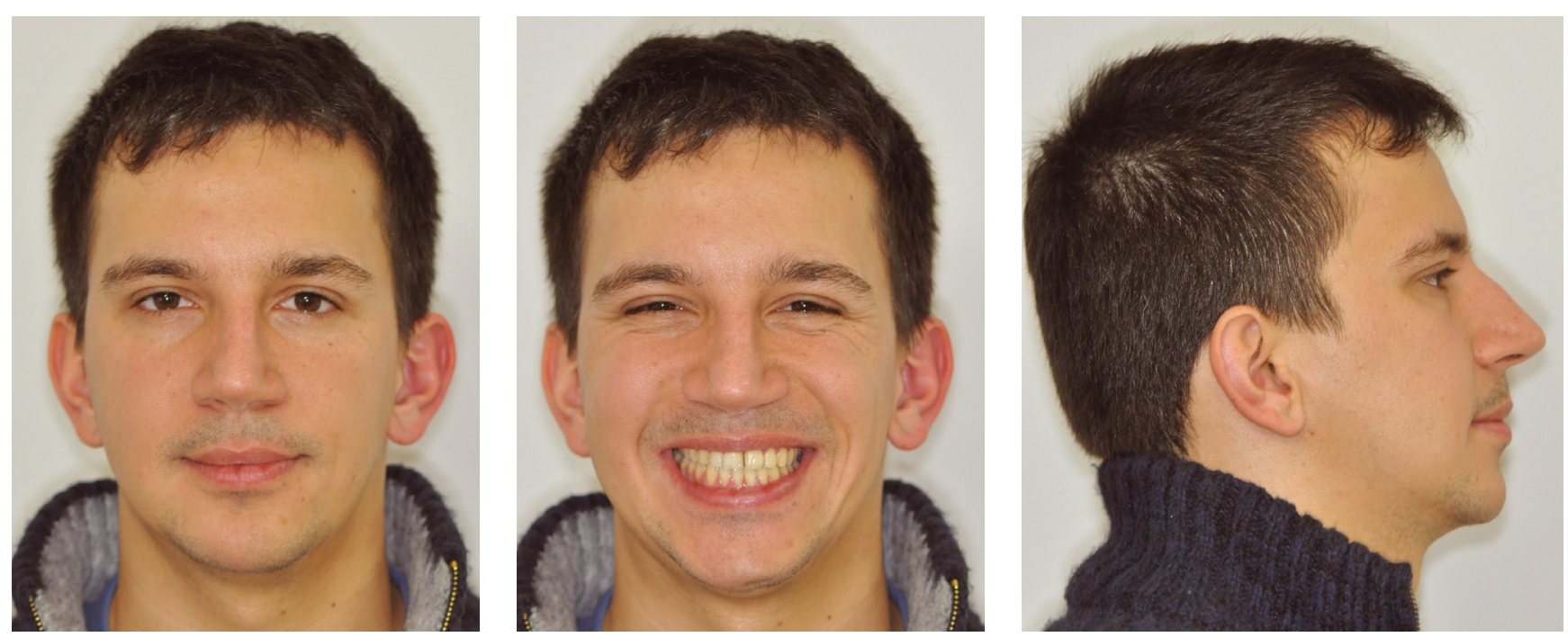

15a., b., c. ábra: Kezelés utáni arcfotók
Végső lemezt nem használtunk, mivel a mandibulát egyszerüen maximális interkuszpidális okklúzióba helyeztük, de a virtuális sebészet segített bennünket
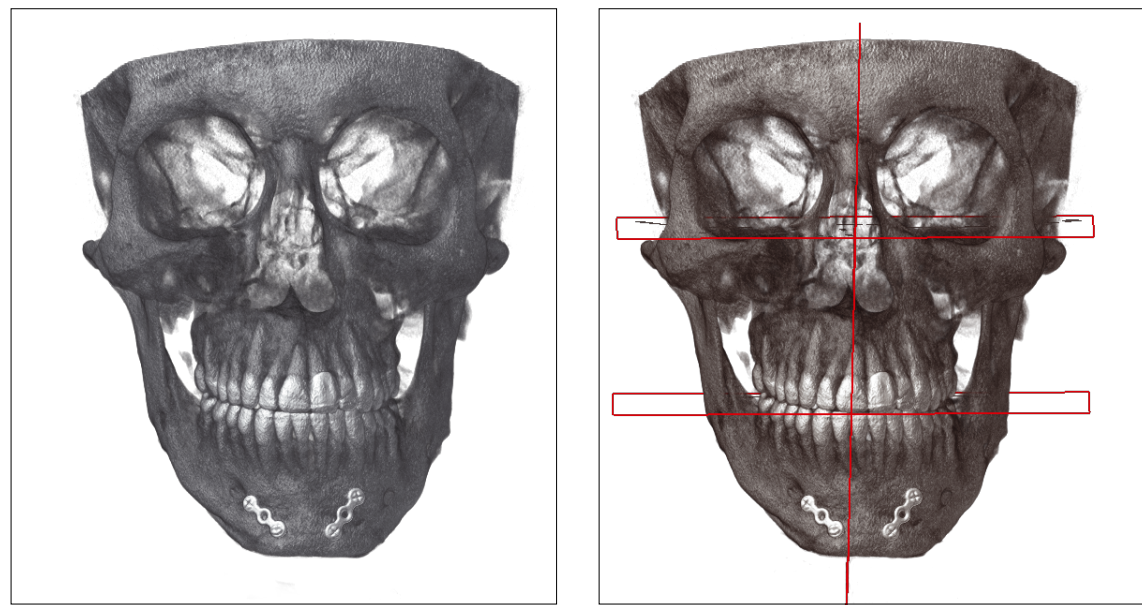

16a., b. ábra: Posztoperatív CT rekonstrukció; referencia-síkokkal
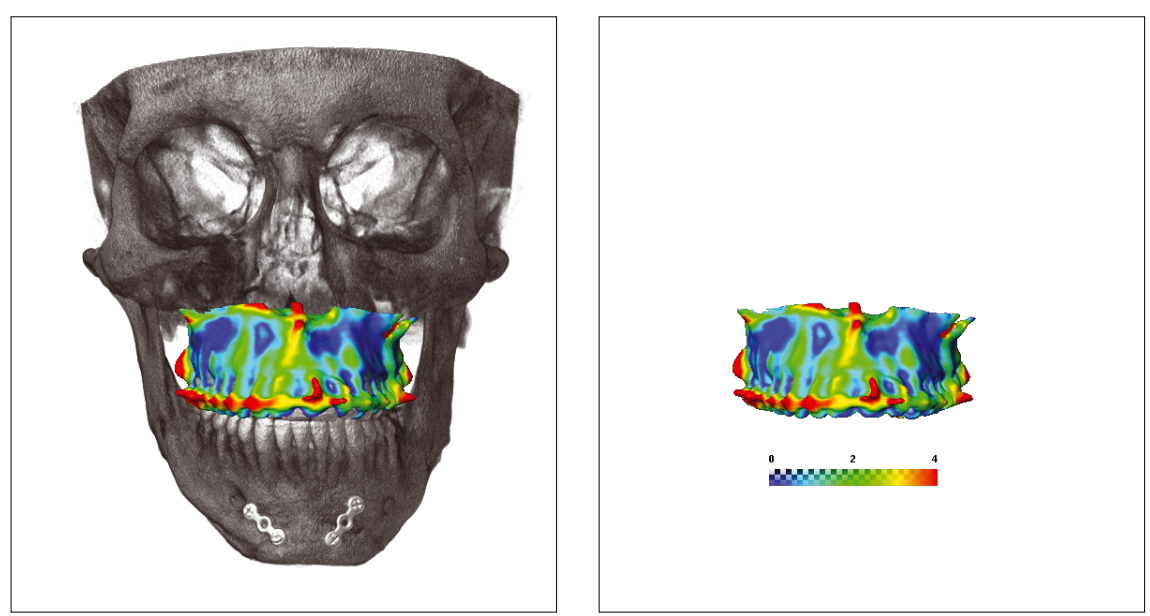

a mandibula rotációs mozgatásának vizualizálásában és megértésében. A hagyományos modell-mütét a fogazatra és az okklúzióra összpontosít, azonban a csontos struktúrákban létrejövő változásokat nem képes kimutatni.

\section{Összegzés}

A számítógépes tervezőprogramok és a háromdimenziós nyomtatás komoly segítséget adhatnak az állcsontkorrekciós mútétek megtervezéséhez és elvégzéséhez. Feleslegessé tehetik a fogtechnikai hátteret, a bonyolult modell-mútét elvégzését. Az információ nem vész el az ortodontus-sebész-fogtechnikus háromszögben. Olyan mérésekre is lehetőség van, amelyeket a hagyományos modell-mútét során nem tudunk elvégezni. A tervezés minimális anyagi és időbeli ráfordítással tetszőleges számban ismételhető. Az okklúziós lemez virtuálisan megtervezhető és háromdimenziós nyomtató segítségével elkészíthető. Ugyan tanulmányunkban csak egy esetet mutatunk be, de ez rámutat arra, hogy a számítógépes szimulációs sebészet különösen hasznos lehet súlyos aszimmetriával járó eseteknél, amikor a kezelés pontos megtervezése hagyományos módszerekkel nehezen lenne lehetséges.

17a., b. ábra: A virtuális terv és a mútét utáni állapot szuperimpozíciója; távolságértékek (mm) 


\section{Irodalom}

1. CHEONG YW, Lo LJ: Facial asymmetry: etiology, evaluation, and management. Chang Gung Med J 2011; 34: 341-351.

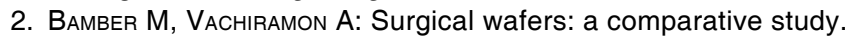
J Contemp Dent Pract 2005; 6: 99-106.

3. CHOI JY, SONG KG, BAEK SH: Virtual model surgery and wafer fabrication for orthognathic surgery. Int J Oral Maxillofac Surg 2009; 38: $1306-1310$.

4. Metzger MC, Hohlweg-Majert B, Schwarz U, Teschner M, Hammer B, SCHMELZEISEN R: Manufacturing splints for orthognathic surgery using three-dimensional printer. Oral Surg Oral Med Oral Pathol Oral Radiol Endod 2008; 105: e1-7.

5. Levine JP, Patel A, SaAdeh PB, Hirsch Dl: Computer-aided design and manufacturing in craniomaxillofacial surgery: the new state of the art. J Craniofac Surg 2012; 23: 288-293.

6. LORENSEN WE, CLINE HE: Marching cubes: A high resolution 3D surface construction algorithm. Computer Graphics 1987; 21: 163-169.

7. ERdöhelyI B, VARGA E, KuBA A: Surgical Planning Tool with Biomechanical Simulation. Proceedings of the International Conference on Computer Assisted Radiology and Surgery (CARS). Int J Comput Assist Radiol Surg 2007; 2: S262-S263.

8. Cevidanes LH, Tucker S, Styner M, Kim H, Chapuis J, Reyes M, Proffit W, Turvey T, Jaskolka M: Three-dimensional surgical simulation. Am J Orthod Dentofacial Orthop 2010; 138: 361-371.

9. ElLIS E 3RD: Accuracy of model surgery: evaluation of an old technique and introduction of a new one. J Oral Maxillofac Surg 1990; 48: $1161-1167$.
10. Edler R, Wertheim D, Greenhill D: Outcome measurement in the correction of mandibular asymmetry. Am J Orthod Dentofacial Orthop 2004; 125: 435-443.

11. Hwang HS, Hwang $\mathrm{CH}$, Lee KH, Kang BC: Maxillofacial 3-dimensional image analysis for the diagnosis of facial asymmetry. $\mathrm{Am}$ J Orthod Dentofacial Orthop 2006; 130: 779-785.

12. Gateno J, Xia JJ, Teichgraeber JF: A new three-dimensional cephalometric analysis for orthognathic surgery. J Oral Maxillofac Surg 2011; 69: 606-622.

13. Baek SH, Kang SJ, Bell WH, Chu S, Kim HK: Fabricating a surgical wafer splint by three-dimensional virtual model surgery. In: Bell WH, Guerrero CA. eds. Distraction Osteogenesis of the Facial Skeleton. Hamilton, Ontario: BC Decker, 2006: 115-130.

14. Swennen GR, Mollemans W, Schutyser F: Three-dimensional treatment planning of orthognathic surgery in the era of virtual imaging. J Oral Maxillofac Surg. 2009; 67: 2080-2092.

15. Hsu SS, Gateno J, Bell RB, Hirsch DL: Markiewicz MR, Teichgraeber JF, Zhou X, Xia JJ. Accuracy of a computer-aided surgical simulation protocol for orthognathic surgery: a prospective multicenter study. J Oral Maxillofac Surg 2013; 71: 128-142.

16. Parbatani R, Williams AC, Ireland AJ, Sandy JR: The process of orthognathic care in an NHS region. Ann R Coll Surg Engl 2010; 92: 34-39.

17. Varga E JR, Hammer B, Hardy BM, Kamer L: The accuracy of threedimensionalmodel generation. What makes it accurate to be used for surgical planning? Int J Oral Maxillofac Surg 2013; 42: $1159-1166$

Seres L, Kocsis A, Varga E, Raskó Z, Varga V, Bagó B, Varga E, Piffkó J

\section{Virtual model surgery and fabrication of a surgical wafer by rapid prototyping technology for correction of a severe mandibular asymmetry}

Correction of a severe facial asymmetry presents a challenge due to the geometric complexity of the dentition, the bony structures and the soft tissues. In most asymmetric cases two-jaw surgery is recommended. Manual model surgery is an essential part of treatment planning but it can be complicated, time-consuming and may contain potential errors. We present a case of a 26-year-old male with a severe right-sided hemimandibular elongation when computerized simulation surgery was performed instead of manual model surgery. High-resolution computer tomography scan was done following presurgical orthodontics and the stack images were reformatted into a three-dimensional structure. The symmetry of the maxilla was corrected via a virtual Le Fort I osteotomy with the help of a three-dimensional planning software. A virtual intermediate surgical wafer was designed and fabricated with a three-dimensional printer. Virtual bilateral sagittal split osteotomy was performed and the mandible was rotated into the correct position to visualize the movements of the osteotomized segments. Real surgery was accomplished according to the virtual plan. The splint fitted well. There is a significant improvement in the facial symmetry; the occlusion is good and stable. This case supports the usage of computer-aided surgical planning and three-dimensional rapid prototyping for the correction of facial asymmetries.

Keywords: virtual model surgery, facial asymmetry, digital intermediate wafer, three-dimensional rapid prototyping 